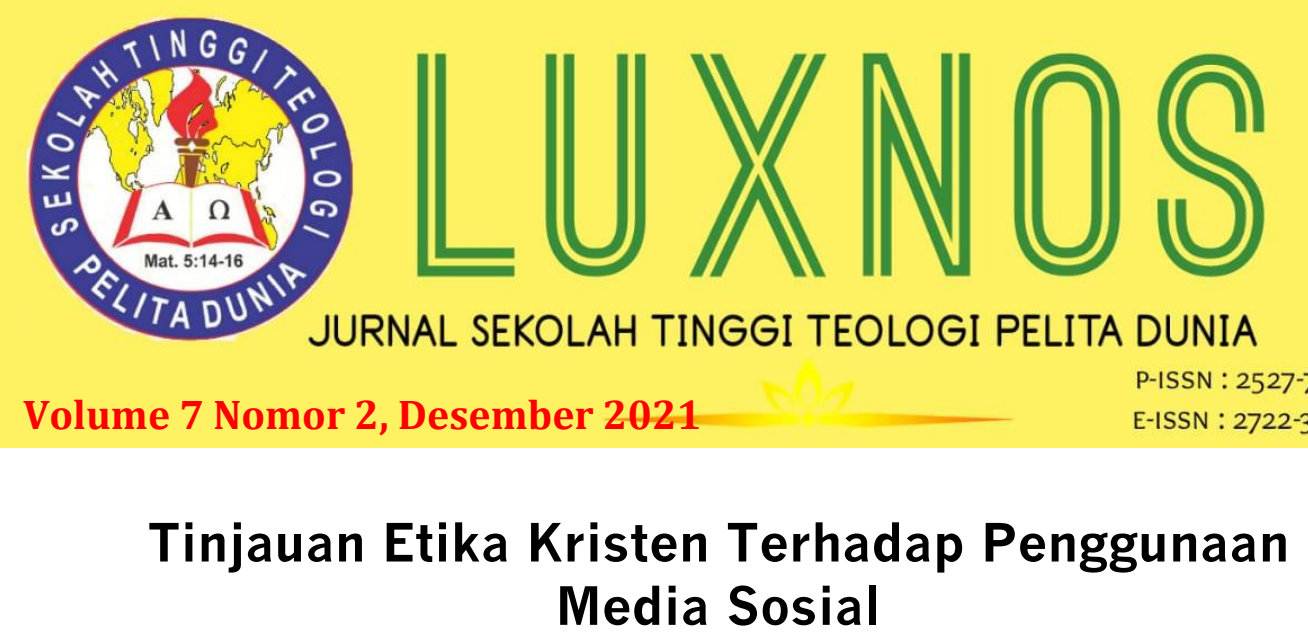

\title{
Yosia Belo
}

Sekolah Tinggi Teologi Injili Arastamar (SETIA) Jakarta

ociebelo42@gmail.com

\begin{abstract}
This study is about a review of Christian ethics on the use of social media. This is done because of the widespread use of negative social media, including among Christians. By using qualitative research methods, especially literature studies, the following conclusions are obtained: Christians must use social media wisely, to witness, for the glory of God, and based on the guidance of the Holy Spirit or not to follow the flesh and satisfy its lusts.

Keywords: Christian Ethics, Social Media, Wisdom, Bible
\end{abstract}

\begin{abstract}
Abstrak: Penelitian ini berbicara tentang tinjauan etika Kristen terhadap penggunaan media sosial. Hal ini dilakukan karena maraknya penggunaan media sosial secara negatif, termasuk di kalangan orang Kristen. Dengan menggunakan metode penelitian kualitatif, khususnya kajian pustaka, maka diperoleh beberapa kesimpulan sebagai berikut: orang Kristen wajib menggunakan media sosial dengan bijaksana, untuk bersaksi, untuk kemuliaan Allah, dan berdasarkan pimpinan Roh Kudus atau bukan untuk mengikuti kedagingan serta memuaskan nafsunya semata.
\end{abstract}

Kata Kunci: Etika Kristen, Media Sosial, Bijaksana, Alkitab

\section{Pendahuluan}

Media sosial merupakan instrumen yang digunakan untuk berelasi dan menjalin komunikasi kepada sesama, di mana dipraktikkan dengan menggunakan jaringan internet, sehingga membuat seseorang dapat berkomunikasi dengan kerabat sekalipun berada pada tempat yang berbeda dan jauh. Perkembangan media sosial saat ini terjadi sangat pesat. Hal ini tidak terlepas dengan perkembangan dan peran IPTEK yang sudah tidak dapat dilepaskan dari dunia sosial masyarakat. 
Berdasarkan riset dan studi yang dilakukan oleh We Are Social pada tahun 2019, pengguna media sosial di Indonesia mencapai hingga 150 juta orang. Hal itu berarti terdapat sekitar $57 \%$ dari seluruh penduduk Indonesia telah menggunakan berbagai media sosial. ${ }^{1}$ Bahkan ada indikasi bahwa pengguna media sosial di Indonesia akan terus bertambah atau meningkat setiap tahunnya. Rakha Fahreza Widyananda menambahkan bahwa ada sepuluh media sosial yang sangat populer digunakan di Indonesia. Media sosial itu adalah Youtube, WhatsApp, Facebook, Instagram, Tiktok, Line, Twitter, Reddit, Pinterest, dan Tumblr. ${ }^{2}$

Secara positif, media sosial dapat digunakan sebagai sarana yang baik dan efektif untuk promosi seperti: promosi barang jualan, promosi makanan, promosi tempat wisata, dan lain-lain. Bahkan media sosial juga seringkali digunakan sebagai media sarana pendidikan, sebagai sarana untuk membangun citra instansi atau organisasi dan digunakan sebagai sarana penyampaian informasi. $^{3}$

Namun, pihak-pihak yang tidak bertanggung jawab juga memakai media sosial untuk kepentingan kelompok mereka dan seringkali berdampak negatif kepada masyarakat umum. Seperti menjamurnya kabar atau berita bohong atau hoaks di media sosial. Melalui media sosial, berita-berita hoaks tumbuh subur karena pada umumnya penggunanya nyaris tidak mengecek kebenaran dari setiap berita hoaks yang dijumpai di media sosial. Selain itu, pengguna media sosial cenderung terprovokasi hingga meneruskan pesan dan informasi kepada jejaring mereka. Bahkan tidak sedikit pengguna media sosial juga kerap menggunakannya untuk hal-hal yang tidak pantas, seperti: untuk pornografi, informasi mengenai perjudian, ajakan kekerasan maupun tindakan kriminal lainnya. ${ }^{4}$

Tidak sampai di situ saja, setiap layanan yang terdapat pada media sosial turut memancing keinginan pihak-pihak tertentu untuk menyalahgunakannya demi kepentingan kelompok mereka dengan mengesampingkan etika moral juga regulasi dan hukum positif di Indonesia. Misalnya, untuk kasus Saracen yang juga semakin mengemuka. Kasus ini berdampak signifikan, secara khusus di Indonesia, terutama untuk kelompok yang belum menyadari bahwa setiap informasi yang mereka dapatkan kemudian membagikannya kembali kepada

\footnotetext{
${ }^{1}$ Rakha Fahreza Widyananda, "10 Macam Media Sosial Yang Paling Sering Digunakan Oleh Orang Indonesia," Merdeka.Com (Jawa Timur, 2020).

2 Ibid.

${ }^{3}$ Joao Martins Bernardus Palapessy, Syahroni, Jose Soares, "PENYALAHGUNAAN MEDIA SOSIAL," Binus Graduate Program, last modified 2018, https://mti.binus.ac.id/2018/04/04/penyalahgunaan-media-sosial/.

${ }^{4}$ Ibid.
} 
orang lain adalah berita hoax yang sengaja dibuat oleh kelompok tertentu untuk berbagai tujuan. Ada pun tujuan yang mereka perjuangkan adalah untuk menggiring opini publik serta menciptakan suasana sesuai dengan keperluan berbagai pihak. Untuk kasus Saracen ini, publik akan dibanjiri informasi yang berbau SARA dan bertujuan untuk memecah belah kesatuan umat dan masyarakat serta memberi image negatif terhadap seseorang atau golongan tertentu. $^{5}$

Kasus penyebaran berita hoax dan berita yang berisi ujaran kebencian begitu tumbuh subur di tengah momentum tahun politik yang ada di Indonesia. Bukan hanya oleh Saracen, media sosial sering menjadi media penyebaran hoax yang secara sengaja serta tidak sengaja disebarluaskan oleh oknum-oknum tertentu. Angka ini terus tumbuh seiring dengan banyaknya oknum yang ingin menuliskan pikiran atau idenya yang berkaitan dengan politik. Kendati saat ini sudah ada regulasi, khususnya undang-undang ITE yang mengatur tentang bagaimana harus bersikap serta berinteraksi di media sosial. Akan tetapi undang-undang ITE ini terlihat belum tersosialisasi dengan baik kepada masyarakat, sehingga masih banyak orang yang tidak mengindahkan peraturan tersebut. ${ }^{6}$

Bahkan media sosial juga seringkali digunakan oleh para tokoh agama serta rohaniwan Kristen untuk berdebat, atau mempersoalkan hal-hal yang bersifat doktrinal, sehingga terkadang itu juga turut disaksikan oleh jemaat awam. Celakanya lagi, karena dalam perdebatan itu justru mereka seringkali saling menghujat, saling memaki hingga mengeluarkan kata-kata kasar di antara sesama hamba Tuhan. Hal inilah yang turut menjadi persoalan penting dalam penggunaan media sosial. Setiap pihak wajib untuk mengetahui dan memperhatikan setiap batasan dalam penggunaan media sosial.

Pada penelitian sebelumnya, Mesirawati Waruwu, Yonatan Alex Arifianto dan Aji Suseno menyimpulkan bahwa jalan keluar bagi gereja ketika menghadapi dekadensi moral akibat penyalahgunaan media sosial dengan era disrupsi serta tantangan etika dari penggunaan media sosial yang salah ternyata dapat mempengaruhi dekadensi moral. Dengan demikian, pendidikan etika Kristen dengan landasan prinsip yang alkitabiah dapat membawa orangorang modern, khususnya orang percaya dapat mengekspresikan terangnya dan

\footnotetext{
5 Ibid.

6 Ibid.
} 
pengaruhnya ketika menggunakan media sosial dan penggunaannya yang sesuai iman Kristen di era disrupsi ini. ${ }^{7}$

Hal yang identik juga dikemukakan oleh Yonatan Alex Arifianto, Priyantoro Widodo pada penelitiannya tentang topik ini dengan mengatakan, bertumbuhnya media sosial dalam kontestasi politik juga memicu perubahan dari peran menyimpang dari esensi makna buzzer. Untuk itu setiap pribadi dapat memaknai bahwa buzzer dalam tinjuan etis Kristiani memang tidak dibenarkan bila hal itu menjadi corong kejahatan terlebih pemecah belah anak bangsa. Untuk itu selanjutnya adanya sikap orang percaya perlu diperhatikan dalam menggunakan media Sosial di seluruh Market Places. Untuk itu adanya sikap hidup dalam kebenaran harus dimiliki oleh setiap orang percaya, terlebih sikap yang menjadi contoh dan teladan dalam bersosial media. Dari sikap tersebut diharap dapat memberi dampak bagi semua orang di sekelilingnya. ${ }^{8}$

Melalui pemaparan tentang permasalahan di atas dan dirangkaikan dengan beberapa hasil penelitian sebelumnya, maka melalui penelitian ini akan dikaji tentang bagaimana penggunaan media sosial secara benar berdasarkan prinsip Alkitab dan etika Kristen, sehingga setiap pengguna media sosial dapat mempergunakannya bukan untuk melakukan kejahatan melainkan untuk maksud yang baik dan positif.

\section{Metode Penelitian}

Adapun metode atau pendekatan yang digunakan dalam kajian ini adalah metode kualitatif, di mana lebih menitikberatkan pada literature research. Pendekatan ini yang dipilih karena dianggap paling cocok dan paling dapat menolong peneliti mendapatkan data yang valid dan terkait dengan topik kajian ini. Pendekatan kualitatif mengutamakan data atau informasi dari hasil penelitian yang telah dilakukan sebelumnya bahkan juga dari buku-buku yang memiliki cakupan penelitian yang sama. ${ }^{9}$ Dengan demikian, diharapkan dapat menolong penulis untuk menemukan sebuah hasil penelitian yang kualitatif yang berkaitan dengan topik ini.

\footnotetext{
${ }^{7}$ Mesirawati Waruwu, Yonatan Alex Arifianto, and Aji Suseno, "Peran Pendidikan Etika Kristen Dalam Media Sosial Di Era Disrupsi," Jurnal Pendidikan Agama Kristen (JUPAK) 1, no. 1 (2020): 43-56.

${ }^{8}$ Yonatan Alex Arifianto and Priyantoro Widodo, "Tinjauan Etis Kristiani Terhadap Buzzer Dalam Media Sosial," Veritas Lux Mea (Jurnal Teologi dan Pendidikan Kristen) 3, no. 1 (2021): 1-16.

${ }^{9}$ Adi Putra and Gunar Sahari, "Penerapan Kepemimpinan Pastoral Yesus Kristus Dalam Kitab Injil Bagi Sekolah Tinggi Teologi Pelita Dunia," Manna Rafflesia 7, no. 2 (2021): 279-302.
} 


\section{Hasil dan Pembahasan}

\section{Dasar Alkitab}

Pada bagian ini akan dibahas beberapa bagian Alkitab yang berbicara bagaimana seorang Kristen dapat menjaga integritasnya dalam perbuatan, tindakan, tutur kata hingga pemikiran, di mana semuanya itu akan teraktualisasi dalam setiap perilaku baik yang tampak ke publik maupun yang tidak, termasuk dalam menggunakan media sosial.

\section{Amsal 2:20-21}

Pada bagian ini penulis Amsal menekankan tentang hikmat, di mana yang ditekankan oleh penulis Amsal adalah bagaimana hikmat itu mengarahkan dan menuntun setiap orang percaya kepada kebenaran sehingga teraktualisasi dalam tindakan praktisnya ( $b d k$. ay. 20). Apabila diperhatikan kedua ayat ini maka berikut ini merupakan penekanan dari kedua ayat di atas. Pertama, jalan orang baik, yang merupakan jalan yang ditempuh orang-orang baik sejak zaman dulu. Kedua, ketika melalui jalan itu, maka dipastikan akan memperoleh kebijaksanaan. Artinya, orang Kristen yang telah dilahirbarukan dan masuk dalam persekutuan dengan Tuhan maka sudah sepatutnya menempuh jalan hidup yang benar termasuk dalam menggunakan media sosial.

John W. Miller mengatakan, konteks bagian ini adalah berbicara tentang wanita dengan kondisi sosial dan psikologis yang cukup spesifik yakni: menikah, jauh dari rumah, dan terang-terangan menggoda. Dia telah meninggalkan pasangan [atau pendamping] masa mudanya dan mengabaikan perjanjian yang dia buat di hadapan Tuhan [lit., melupakan perjanjian Tuhannya]. Perjanjian yang dimaksud mungkin bukan perjanjian yang dia buat pada pernikahannya tetapi perjanjian Israel dengan Tuhan, yang melibatkan orang-orang terkenal tertentu perintah yang salah satunya melarang keras perzinahan (Ul. 5:18; lihat 5:18-20; Kejadian 2:24; Mal 2:14). Di latar belakang di sini adalah Perkawinan yang terbentuk di kalangan remaja melalui proses yang melibatkan pilihan dan persetujuan orang tua (lih. Kej 29:21-28). Stabilitas dan daya tahan pernikahan semacam itu sangat parah terancam punah oleh wanita dari jenis yang dijelaskan. Dalam puisi khusus ini terminologi dan cita-cita perjanjian adalah orang-orang dari Hizkia yang membuat ajaran di sini sebagai suplemen untuk Puisi Edisi Salomo dalam Amsal 5:1-14 [Pendekatan Khas]. Nasib mereka yang cukup bodoh untuk terlibat dengan seorang wanita seperti ini dijelaskan dalam 
gambar suram. Seluruh rumahnya miring atau tenggelam menuju akhirat, dan begitu juga semua orang di dalam yang bergaul dengan dia (2:18-19). ${ }^{10}$

Artinya, setiap orang Kristen tidak boleh lagi dipimpin oleh nafsu dan keinginannya sendiri dalam melakukan segala sesuatu dalam kehidupannya. Oleh karena orang Kristen telah ditebus dan menjadi milik Kristus. Jangan lagi menyerahkan hidupmu kepada hal-hal yang bersifat kedagingan, nawa nafsu, perzinaan, dll. Demikian halnya dalam menggunakan media sosial, yang cenderung godaan dalam hal-hal seperti di atas sangat banyak. Sehingga apabila seorang Kristen senantiasa menuruti hawa nafsunya maka pasti akan terjerumus dan jatuh di dalamnya. Oleh karena itu, setiap orang Kristen harus bijaksana dalam menjalani hidupnya, jangan lagi menjadi serupa dengan dunia ini.

\section{Matius 5:13-16}

Bagian ini masuk dalam perikop dari khotbah Tuhan Yesus di atas bukit. Di mana pada bagian ini Yesus menegaskan perihal kehidupan pengikut Kristus yang dianalogikan sebagai garam dan terang dunia. Menurut Yunus Selan, ungkapan "kamu adalah terang" dalam Matius 5:14 dapat dimaknai atau dapat dipahami sebagai terang Kristus yang dimiliki oleh setiap orang Kristen. Setiap orang Kristen merefleksikan terang Kristus kepada dunia supaya dunia dapat melihat terang-Nya. Hal ini kemudian dapat diimplementasikan dalam tiga tugas utama setiap hamba Tuhan, yakni: menjadi teladan, menjadi pembimbing dan penasihat, dan memberikan peringatan kepada setiap jemaat. ${ }^{11}$

Sedangkan untuk garam dunia dimaknai bahwa: pertama, setiap orang percaya adalah seperti garam, patut untuk hidup berbeda dengan dunia dengan memiliki identitas khusus dan memainkan peranan di berbagai bidang dalam dunia pada masa kini. Kedua, setiap orang percaya pada masa kini patut mempertahankan apa yang sudah baik di dalam dunia seperti senantiasa memperlihatkan sikap harmonis kepada sesama (Mrk. 9:50). Ketiga, setiap orang percaya pada masa kini patut mengembangkan (menyuburkan) apa yang sudah baik dalam dunia ini sehingga menjadi lebih baik lagi. ${ }^{12}$ Menurut Leon Morris, kita harus melihat garam sebagai metafora dan dunia menunjuk kepada orang banyak. Yesus tampaknya memikirkan fungsi garam sebagai pengawet, lawan

10 John W. Miller, Believers Church Bible Commentary: Proverbs (Scottdale, Pennsylvania Waterloo, Ontario: Herald Press, 1926), 48-49.

11 Yunus Selan, "MAKNA UNGKAPAN" Kamu Adalah Terang Dunia" MENURUT MATIUS 5: 14 DAN PENERAPANNYA DALAM PELAYANANAN HAMBA TUHAN," JURNAL LUXNOS 6, no. 1 (2020): 1-6.

12 Ndaru Sarjono and Gunar Sahari, "MAKNA UNGKAPAN" Kamu Adalah Garam Dunia" DALAM MATIUS 5: 13 DAN PENERAPANNYA BAGI ORANG PERCAYA MASA KINI," JURNAL LUXNOS 6, no. 2 (2020): 151-159. 
bagi kebusukan, dan pencita rasa makanan. Kemudian terang di sini harus terwujud dalam perbuatan baik yang dilihat oleh banyak orang. ${ }^{13} \mathrm{~J}$. J. de Heer juga mengatakan, tetapi yang ditekankan di sini adalah pentingnya setiap orang Kristen memperlihatkan perbuatan-perbuatan yang baik dalam kehidupannya setiap hari. Hal ini akan membuat dunia menjadi terheran-heran atas perbuatanperbuatan itu, serta mempermuliakan Tuhan, yang memberikan kekuatan kepada orang Kristen untuk berbuat begitu. ${ }^{14}$

Demikianlah setiap orang percaya dalam menggunakan media sosial sudah sepantasnya untuk senantiasa menempatkan dirinya sebagai garam dan terang dunia. Sebagai garam yang bertujuan untuk mempengaruhi orang lain dengan perbuatan-perbuatan yang baik sehingga melaluinya mereka dapat mengenal kebenaran dalam Yesus Kristus. Kemudian sebagai terang yang bertujuan untuk menerangi orang lain dengan terang Kristus dan Injil Kristus, sehingga media sosial yang digunakannya menjadi sarana baginya untuk bersaksi dan untuk memberitakan kebenaran Injil Kristus.

\section{Korintus 10:31}

Berdasarkan ayat ini, dapat dilihat dengan jelas tentang penegasan Paulus yang hendak menegaskan tentang sasaran utama dari kehidupan gereja atau orang Kristen adalah melakukan apa yang dikehendaki oleh Allah serta memprioritaskan kemuliaan-Nya dalam setiap aspek kehidupan dan tindakannya. V. C. Pfitzner mengatakan, orang Kristen mula-mula, yang hidup di lingkungan kafir, dengan mudah dapat mengembangkan kehidupan yang penuh rasa takut, mengajukan beberapa pertanyaan tentang setiap makanan, terusmenerus berjaga-jaga dan membayangkan segala sesuatu fitnahan dan ocehan orang lain tentang diri mereka. Perilaku yang penuh dengan ketakutan itu adalah penyangkalan terhadap kemerdekaan Kristen. ${ }^{15}$ Ditambahkan lagi oleh Pfitzner, orang percaya itu bebas dari pandangan-pandangan dan penilaian-penilaian manusia untuk makan dan minum atau melakukan segala sesuatu yang lain. Tetapi ia bebas bukan untuk dirinya sendiri, untuk melakukan apa yang ia inginkan, melainkan untuk Allah. Ia telah dibebaskan dari perhambaan dosa, untuk melakukan segala sesuatu itu untuk kemuliaan Allah. Allah tidak dimuliakan oleh ketaatan seperti seorang hamba pada peraturan-peraturan yang legalistik, ataupun oleh kebisuan. Seluruh kehidupan haruslah menjadi suatu

13 Leon Morris, Tafsiran Injil Matius (Surabaya: Momentum, 2016), 111-112.

${ }^{14}$ J.J. de Heer, Tafsiran Alkitab Injil Matius (Jakarta: BPK Gunung Mulia, 2003), 76.

15 V.C. Pfitzner, Ulasan Atas 1 Korintus: Kesatuan Dalam Kepelbagaian (Jakarta: BPK Gunung Mulia, 2008), 194. 
liturgi pujian, suatu pelayanan kepada Allah dan sesama manusia (Kol. 3:17). ${ }^{16}$ Senada dengan Pfitzner di atas, R. Dean Anderson juga berpendapat bahwa, bagian ini menekankan bahwa dalam segala hal, termasuk makanan dan minuman, kemuliaan Allah yang harus diutamakan (bdk. Kol. 3:17, 23). ${ }^{17}$

Dengan demikian, dalam menggunakan media sosial, setiap orang Kristen dituntut untuk senantiasa menjaga kekudusan dirinya, baik dalam hal yang bersifat moral, maupun dalam hal menjaga integritasnya dan kekudusannya. Oleh karena segala aspek dan totalitas hidup orang percaya bukan lagi diperuntukkan untuk melayani dan melakukan tindakan-tindakan yang tercela melainkan untuk melayani dan mempermuliakan Allah.

\section{Galatia 5:22-23}

Paulus menjelaskan tentang sesuatu yang kontras dengan apa yang telah dijelaskan sebelumnya, yakni tentang buah, bukan tentang apa yang diperbuat; Roh dan bukan tentang kedagingan. Kemudian dilengkapi dengan kumpulan kebijaksanaan, di mana semuanya itu dapat menarik dan layak diinginkan. Apabila memperhatikan teks Yunaninya, maka ungkapan "buah" itu berbentuk tunggal. Di mana tendensinya hendak menekankan pada kesatuan dan kesatupaduan dari hidup di dalam Roh serta bertentangan dengan kekacauan dan ketidakteraturan dari hidup yang masih dipengaruhi oleh kedagingan. Bahkan juga bentuk tunggal ini digunakan untuk menunjuk kepada oknum Kristus di dalam siapa semua hal ini tampak secara sempurna. Roh berusaha menghasilkan semua ini dengan melahirkan Kristus di dalam diri orang percaya (bdk. 4:19).

Paulus menggambarkan "daging" di bawah istilah pekerjaan, sementara dia melihat pekerjaan Roh sebagai "buah". Yang pertama adalah jamak sedangkan yang kedua adalah tunggal. Apakah ada sesuatu signifikan dalam perubahan istilah atau perubahan nomor? Di atas segalanya, itu harus diperhatikan bahwa karya telah menjadi istilah asosiasi negatif di Galatia dan bahwa Paulus mungkin senang mengaitkan "perbuatan" daging dengan "melakukan hukum Taurat" $(2: 16 ; 3: 2,5,10)$. Perubahan istilah menjadi "buah" membangkitkan citra yang berbeda: dari salah satu tanggung jawab manusia ke salah satu ilahi pemberdayaan. Gambar buah memiliki rasa kepasifan tertentu; ini adalah Roh

16 Ibid.

17 R. Dean Anderson, Tafsiran Perjanjian Baru Surat 1 Korintus: Membereskan Jemaat Urban Yang Muda, ed. Irwan Tjulianto (Surabaya: Momentum, 2018), 237. 
Allah yang menghasilkan hal-hal seperti itu, dan mereka tumbuh dalam kehidupan Kristen. ${ }^{18}$

Namun, sementara ini mungkin menjadi salah satu alasan untuk perubahan persyaratan, itu juga jelas bahwa Paulus melihat kejahatan sebagai buah (6:8) dan berpikir bahwa orang Kristen adalah bertanggung jawab untuk membiarkan Roh bekerja dalam hidupnya. Perhatikan bahwa Paulus memikul tanggung jawab buah Roh kepada orang Kristen: "telah menyalibkan daging mereka” (ay. 24), "marilah kita mengikutinya" (ay. 25), dan "janganlah kita menjadi sombong" (ay. 26)-belum lagi ayat 13,16 , dan 18. Mungkin saja kesatuan buah ditekankan dalam bentuk tunggal sementara banyak kacau dosa daging diwakili dalam kata benda jamak. Sebaliknya, "buah" dapat dilihat sebagai jamak kolektif; jika demikian, tidak ada yang signifikan dalam berubah menjadi tunggal. ${ }^{19}$

Menurut James A. Fowler, setelah mendaftarkan perilaku-perilaku ini, Paulus mengatakan langsung kepada penerima suratnya di Galatia, "Aku memperingatkan kamu sebelumnya sama halnya dengan yang telah kusampaikan kepadamu sebelumnya, bahwa orang yang masih hidup dalam kedagingan atau perbuatan-perbuatan daging tidak akan mendapat bagian dalam Kerajaan Allah." "Sama seperti saya memperingatkan dan memperingatkan Anda ketika saya hadir dengan Anda dan memberitakan Injil untuk pertama kalinya (lih. Kis 13:14 - 14:24), saya katakan lagi sebelumnya, memperingatkan Anda tentang penghakiman Allah, bahwa mereka orang-orang yang terus berperilaku dengan cara-cara ini, dan terus mempraktekkan tindakan-tindakan ini dalam pola perilaku yang tidak peduli dan terbiasa, gagal dan menolak untuk menggunakan kebebasan teleologis mereka untuk mengekspresikan karakter Allah dalam tujuan kemanusiaan yang dipulihkan di dalam Kristus, mereka membuktikan bahwa mereka belum menerima "buah sulung Roh" (Rm. 8:23), "janji milik pusaka kita” (2Kor. 1:22; Ef. 1:14) di dalam hadirat Yesus Kristus, dan dengan demikian tidak akan berpartisipasi dalam penyempurnaan dan kesinambungan masa depan dari pemerintahan Kristus di kerajaan yang kekal."20

Dengan demikian, setiap orang Kristen diharuskan dan diwajibkan untuk senantiasa menjaga sikap dan perilaku baik di depan publik maupun yang tidak terlihat oleh sesama. Oleh karena apabila tidak dapat melakukan hal tersebut,

18 Scot McKnight, The NIV Application Commentary: Galatians (Michigan, USA: Zondervan Publishing House, Grand Rapids, 1995), 271.

19 Ibid.

20 James A. Fowler, A Commentary on the Epistle to the Galatians: The Gospel versus Religion (California: C.I.Y. Publishing, 2006). 
maka Tuhan akan memberikan penghakiman dan penghukuman yang setimpal dengan perbuatan mereka.

\section{Prinsip Etika Kristen dalam Menggunakan Media Sosial}

Berikut dikemukakan beberapa prinsip etika Kristen ketika menggunakan media sosial dalam aktivitasnya setiap hari. Setiap prinsip yang dikemukakan di sini didasarkan pada penjelasan dasar Alkitab yang telah dikemukakan sebelumnya.

\section{Orang Kristen Menggunakan Media Sosial dengan Bijaksana}

Setiap orang Kristen menggunakan media sosial dengan bijaksana artinya setiap orang Kristen harus senantiasa memperhatikan hukum dan aturan sesuai dengan standar Alkitab. Oleh karena Alkitab sebagai kebenaran adalah sumber etika mutlak dalam kehidupan setiap orang Kristen. Seperti yang dikemukakan oleh Jan A. Boersema bahwa etika Kristen adalah pertimbangan-pertimbangan tentang kelakuan moril, dari sudut pandang yang disediakan dalam Alkitab. ${ }^{21}$ Artinya, segala sesuatu yang diperbuat termasuk dalam hal menggunakan media sosial harus didasarkan pada standar kebenaran Firman Tuhan. Sehingga apabila menurut Alkitab itu ternyata keliru atau salah, maka sebaiknya orang Kristen menghentikannya.

Lebih lanjut Glen H. Stassen dan David P. Gushee menjelaskan tentang kebijaksanaan. Mereka mengatakan, hal ini terkait dengan kualitas seseorang yang membuat orang itu menjadi seorang yang baik dalam komunitas, dan yang berkontribusi untuk kebaikan komunitas, atau demi kebaikan yang untuknya manusia dirancang. Ada berbagai kualitas karakter. Misalnya, seorang yang baik memiliki integritas dan mencari keadilan. ${ }^{22}$ Dengan demikian, sebagai murid Kristus, sebagai orang yang telah dibenarkan dan sebagai hamba Kristus, sudah sepatutnya bertindak bijaksana dalam menggunakan media sosial, supaya tidak terjerumus dalam penyalahgunaan media sosial untuk hal-hal yang tercela dan jahat di mata Tuhan.

\section{Orang Kristen Menggunakan Media Sosial untuk Bersaksi}

Bersaksi adalah tugas utama setiap orang Kristen. Seperti yang telah diamanatkan oleh Yesus dalam Matius 28:18-20. Di mana setiap orang Kristen wajib untuk menjadi saksi. Tindakan untuk menjadi saksi dapat juga dilakukan

21 Jan A. Boersema, Etika Kristen Sebuah Pengantar, ed. Stenly R. Paparang; Edward E. Hanock (Jakarta: Delima, 2014), 32.

22 Glen H. Stassen; David P. Gushee, Etika Kerajaan: Mengikut Yesus dalam Konteks Masa Kini, ed. Solomon Yo (Surabaya: Momentum, 2008), 19-20. 
melalui media sosial. Artinya, setiap orang Kristen yang menggunakan media sosial perlu memperhatikan dengan baik supaya setiap postingan dan tindakannya di media sosial dapat memberikan dampak positif, dapat menyatakan kebenaran Allah, dapat menerangi dengan terang Injil, dan dapat menularkan hal-hal positif. Hal inilah yang seharusnya dilakukan.

Mesirawati Waruwu, Yonatan Alex Arifianto, dan Aji Suseno mengatakan, setiap orang Kristen dipanggil menjadi terang demi mengekspresikan jati dirinya sebagai pengikut Kristus yang sejati bahkan termasuk di media sosial. Media sosial menjadi sumber daya bagi orang percaya apabila dimanfaatkan dengan baik dan bijak, untuk penatalayanan dalam melaksanakan Amanat Agung di era digital. Setiap gereja Tuhan dituntut untuk menjadi teladan bagi orang lain dalam perkataan di media sosial, seperti yang di katakan Alkitab dalam Efesus 4:29. Dengan demikian, pemahaman kebenaran Firman Tuhan harus menjadi dasar kuat dalam pertumbuhan iman, dan juga dalam setiap pergaulan di mana saja secara khusus di media sosial. ${ }^{23}$

Menurut Waruwu, Arifianto dan Suseon, media sosial bisa menjadi peluang yang besar bagi orang Kristen untuk membangun orang lain melalui setiap perkataan yang kita sampaikan melalui media sosial seperti Facebook dan Twitter. "Setiap orang percaya harus mampu menjadi terang dengan mengaplikasikan pengetahuan yang dimiliki untuk menjadi berkat bagi banyak orang, serta menjadi agen perubahan seperti garam dan terang yang mempengaruhi dan bukan di pengaruhi. Ketika menggunakan media sosial, orang Kristen pun dituntut bertanggung jawab untuk memastikan bagaimana cara berinteraksi di dalamnya, harus menghormati orang lain dan mencerminkan karakter Kristus. Maka itu mengendalikan diri harusnya juga dimiliki oleh setiap orang Kristen, agar tindakan yang dilakukan secara bebas tidak melanggar batasan atau tidak menyinggung perasaan dan kepentingan orang lain. Apabila telah melakukan perbuatan demikian, maka gereja akan memberikan dampak bagi pembangunan tubuh Kristus. ${ }^{24}$ Dengan demikian, tugas untuk bersaksi dapat juga dilakukan di media sosial, sehingga dengan menggunakan media sosial, setiap orang Kristen dapat menjadi berkat, menjadi contoh, mempengaruhi orang lain dengan hal-hal yang positif, hingga menyebarkan Firman Tuhan (Injil) kepada orang lain.

\section{Orang Kristen menggunakan Media Sosial untuk kemuliaan Allah}

${ }^{23}$ Waruwu, Arifianto, and Suseno, "Peran Pendidikan Etika Kristen dalam Media Sosial Di Era Disrupsi."

${ }^{24}$ Ibid. 
Tugas setiap orang Kristen adalah menegakkan dan menyatakan kemuliaan Allah di tengah-tengah dunia yang telah terdistorsi oleh dosa. Karena untuk tugas itulah Tuhan menyelamatkan orang Kristen dan memanggil mereka masuk ke dalam persekutuan bersama dengan Kristus supaya melalui kehidupannya dapat memuliakan Allah.

John Stott mengatakan, inilah panggilan Allah untuk menjadikan seseorang menjadi murid yang radikal, yakni non-konformitas yang radikal terhadap budaya yang ada di sekitar kita. Ini adalah sebuah panggilan untuk menumbuhkan sebuah budaya alternatif (counter culture) Kristiani, sebuah panggilan untuk terlibat namun tidak berkompromi. ${ }^{25}$

Mempermuliakan Allah dapat diartikan dan dipahami memuji dan meninggikan setiap atribut-Nya, yakni: kekudusan, kesetiaan, kemurahan, belas kasih, kasih, kemegahan, kedaulatan, kuasa, dan ke-Mahatahuan-Nya. Selain itu, memuliakan Allah berarti mengulangi dan merenungkannya dalam pikiran dan memberi tahu kepada setiap sesama tentang satu-satunya jalan kesalaman yang telah Ia sediakan. Dengan demikian memuliakan adalah dengan menjaga kekudusan kita. Karena apabila telah berhasil menjaga kekudusan maka itu sudah sama dengan setia, memiliki kasih dan menghormati kedaulatan Allah.

J. C. Ryle menjelaskan dengan sangat baik tentang apa itu kekudusan apabila ditinjau dari perspektif orang Kristen. Menurutnya, kekudusan adalah kebiasaan yang dilakukan seseorang yang selaras dengan kehendak Allah atau tepatnya dikehendaki oleh Allah. Di mana hal ini dapat terwujud apabila seseorang berjuang untuk menjauhi setiap perbuatan yang jahat dan mengupayakan untuk senantiasa taat kepada hukum dan perintah Tuhan. Berdasarkan penjelasan di atas, maka kekudusan juga dapat diartikan sebagai usaha untuk memiliki hidup yang serupa dengan Kristus, serta menjalani hidup yang penuh keyakinan dan percaya kepada Yesus serta menimba dari pada-Nya damai sejahtera dan kekuatan setiap hari. ${ }^{26}$ Artinya memuliakan Allah berarti membiasakan diri untuk melakukan kehendak Allah, selalu berusaha untuk menjauhi kejahatan sambil senantiasa taat melakukan perintah Allah, dan senantiasa mengupayakan untuk memiliki hidup yang serupa dengan Kristus. Dengan demikian, setiap orang Kristen yang dipanggil masuk dalam persekutuan dengan Kristus sudah sepatutnya melakukan segala sesuatu yang mempermuliakan Allah, termasuk dalam menggunakan media sosial.

${ }^{25}$ John Stott, The Radical Disciple: Delapan Aspek Utama Dari Pemuridan Kristen Yang Sejati (Surabaya: Literatur Perkantas Jawa Timur, 2017), 16-17.

26 J.C. Ryle, Aspek-Aspek Kekudusan (Surabaya: Momentum, 2003), 23-24. 
Orang Kristen menggunakan Media Sosial Berdasarkan pimpinan Roh Kudus bukan untuk memuaskan kedagingannya

Setiap orang Kristen yang dipimpin oleh Roh Kudus pasti berperilaku yang dapat memuliakan Allah. Termasuk dalam menggunakan media sosial, apabila dipimpin Roh Kudus maka dalam menggunakannya akan senantiasa mengikuti arahan Roh Kudus. Adi Putra juga mengatakan bahwa peran Roh Kudus begitu signifikan dalam kehidupan orang Kristen, ${ }^{27}$ sehingga mereka tidak akan menyalahgunakan media sosial untuk menggunakan hal-hal yang mendukakan Tuhan.

Apabila telah dipimpin oleh Roh Kudus maka mustahil untuk dapat lagi menuruti keinginan daging dan dunia ini. Hal ini pun akan berdampak kepada penggunaan media sosial. Orang Kristen cenderung mempergunakannya untuk hal-hal yang bermanfaat untuk membangun, mendidik dalam kebenaran dan untuk saling menguatkan dalam Tuhan, seperti membuat video-video yang berisi tentang renungan-renungan Kristen, berbagi kesaksian tentang penyertaan Tuhan hingga mempublis kegiatan-kegiatan lainnya yang sifatnya membangun.

Dengan demikian, tujuan Roh Kudus dalam kehidupan orang Kristen akan dapat terealisasi dengan baik dan sempurna. Kemudian, melalui postinganpostingan demikian, akan dapat mengimbangi postingan-postingan yang negatif di media sosial. Selain itu, setiap orang Kristen dapat saling menjaga dan mengingatkan dalam media sosial.

\section{Kesimpulan}

Melalui kajian yang menitikberatkan pada tinjauan etis, maka diperoleh kesimpulan bahwa penting bagi setiap orang Kristen untuk mempergunakan media sosial dengan pertimbangan-pertimbangan etis yang didasarkan kepada kebenaran Alkitab dan pimpinan Roh Kudus, sehingga setiap orang Kristen tidak mudah terjerumus dan jatuh dalam dosa-dosa dan kesalahan-kesalahan menggunakan media sosial. Dalam hal ini, orang Kristen wajib menggunakan media sosial dengan bijaksana, untuk bersaksi, untuk kemuliaan Allah, dan berdasarkan pimpinan Roh Kudus, bukan untuk mengikuti kedagingan serta memuaskan nafsunya semata.

\section{Referensi}

Anderson, R. Dean. Tafsiran Perjanjian Baru Surat 1 Korintus: Membereskan Jemaat Urban Yang Muda. Edited by Irwan Tjulianto. Surabaya: Momentum,

27 Adi Putra, "Hakikat Pertumbuhan Gereja Berdasarkan Kisah Para Rasul 2: 41-47," BIA': Jurnal Teologi dan Pendidikan Kristen Kontekstual 3 (2020): 262-281. 
2018.

Arifianto, Yonatan Alex, and Priyantoro Widodo. "Tinjauan Etis Kristiani Terhadap Buzzer Dalam Media Sosial." Veritas Lux Mea Uurnal Teologi dan Pendidikan Kristen) 3, no. 1 (2021): 1-16.

Bernardus Palapessy, Syahroni, Jose Soares, Joao Martins. "PENYALAHGUNAAN MEDIA SOSIAL." Binus Graduate Program. Last modified 2018. https://mti.binus.ac.id/2018/04/04/penyalahgunaan-media-sosial/.

Boersema, Jan A. Etika Kristen Sebuah Pengantar. Edited by Stenly R. Paparang; Edward E. Hanock. Jakarta: Delima, 2014.

Fowler, James A. A Commentary on the Epistle to the Galatians: The Gospel versus Religion. California: C.I.Y. Publishing, 2006.

Gushee, Glen H. Stassen; David P. Etika Kerajaan: Mengikut Yesus Dalam Konteks Masa Kini. Edited by Solomon Yo. Surabaya: Momentum, 2008.

Heer, J.J. de. Tafsiran Alkitab Injil Matius. Jakarta: BPK Gunung Mulia, 2003.

McKnight, Scot. The NIV Application Commentary: Galatians. Michigan, USA: Zondervan Publishing House, Grand Rapids, 1995.

Miller, John W. Believers Church Bible Commentary: Proverbs. Scottdale, Pennsylvania Waterloo, Ontario: Herald Press, 1926.

Morris, Leon. Tafsiran Injil Matius. Surabaya: Momentum, 2016.

Pfitzner, V.C. Ulasan Atas 1 Korintus: Kesatuan Dalam Kepelbagaian. Jakarta: BPK Gunung Mulia, 2008.

Putra, Adi. "Hakikat Pertumbuhan Gereja Berdasarkan Kisah Para Rasul 2: 4147." BIA': Jurnal Teologi dan Pendidikan Kristen Kontekstual 3 (2020): 262281.

Putra, Adi, and Gunar Sahari. "Penerapan Kepemimpinan Pastoral Yesus Kristus Dalam Kitab Injil Bagi Sekolah Tinggi Teologi Pelita Dunia." Manna Rafflesia 7, no. 2 (2021): 279-302.

Ryle, J.C. Aspek-Aspek Kekudusan. Surabaya: Momentum, 2003.

Sarjono, Ndaru, and Gunar Sahari. "MAKNA UNGKAPAN" Kamu Adalah Garam Dunia" DALAM MATIUS 5: 13 DAN PENERAPANNYA BAGI ORANG PERCAYA MASA KINI." JURNAL LUXNOS 6, no. 2 (2020): 151-159.

Selan, Yunus. "MAKNA UNGKAPAN" Kamu Adalah Terang Dunia" MENURUT MATIUS 5: 14 DAN PENERAPANNYA DALAM PELAYANANAN HAMBA TUHAN." JURNAL LUXNOS 6, no. 1 (2020): 1-6.

Stott, John. The Radical Disciple: Delapan Aspek Utama Dari Pemuridan Kristen Yang Sejati. Surabaya: Literatur Perkantas Jawa Timur, 2017.

Waruwu, Mesirawati, Yonatan Alex Arifianto, and Aji Suseno. "Peran Pendidikan Etika Kristen Dalam Media Sosial Di Era Disrupsi." Jurnal Pendidikan Agama Kristen (JUPAK) 1, no. 1 (2020): 43-56. 


\section{JURNAL LUXNOS \\ Volume 7 Nomor 2, Desember 2021}

Widyananda, Rakha Fahreza. "10 Macam Media Sosial Yang Paling Sering Digunakan Oleh Orang Indonesia." Merdeka.Com. Jawa Timur, 2020. 